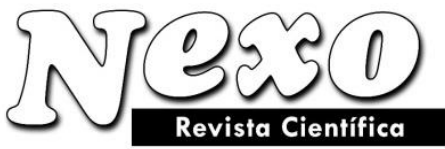

Vol. 34, No. 01, pp. 370-378/Marzo 2021

\title{
Sustainable development in the light of the philosophy of science and ethics
}

\section{Desarrollo sostenible a la luz de la filosofía de la ciencia y la ética}

\author{
Victor Andreevich Kanke, ${ }^{1, *}$, Vladimir Korotenko ${ }^{2,3}$, V.N. Remarchuk ${ }^{4}$, Mikhail Viktorovich \\ Kibakin $^{5}$, Maria Mikhailovna Kryukova ${ }^{6}$ \\ ${ }^{1}$ Obninsk Institute for Nuclear Power Engineering of National Research Nuclear University "MEPhI", \\ Obninsk, Kaluga Region, Russia. \\ ${ }^{2}$ National Academy of Sciences of the Kyrgyz Republic, Bishkek, Kyrgyzstan. \\ ${ }^{3}$ Ecological Movement "Biom”, Bishkek, Kyrgyzstan. \\ ${ }^{4}$ Bauman Moscow State Technical University, Moscow, Russia. \\ ${ }^{5}$ Financial University under the Government of the Russian Federation, Moscow, Russia. \\ ${ }^{6}$ Educational institution School No. 1360, Moscow, Russia. \\ *kanke@obninsk.ru
}

(recibido/received: 22-November-2020; aceptado/accepted: 05-January-2021)

\begin{abstract}
The present article provides a substantiation of the need to use the potential of the philosophy of science in designing a sustainable development project. Along with mathematics and informatics, the philosophy of science is viewed as an auxiliary science designed to help clarify the conceptual and methodological nature of scientific theories. New provisions of science philosophy are presented. The proposition that all axiological theories culminate in ethics is proved. It is also substantiated that natural sciences demonstrate ethical relativity. The project, i.e. both the concept and conception (theory) of sustainable development was designed with no consideration of the achievements of science philosophy including scientific ethics. As the project developed its content became not clearer but, on the contrary, more obscured. The project of sustainable development is reevaluated in light of the philosophy of science. It turns out to be nothing more than a paraphrase of the need for the proper development of the ethical relativity of ecology and its place in the system of balanced scientific ethics. The project of sustainable development presents a paraphrase of certain scientific content that has to be properly addressed. Without this, it has no scientific meaning and should be attributed to the field of everyday language. Thus, the time to put the sustainable development project on a scientific track has come.
\end{abstract}

Keywords: Sustainable development project, Philosophy of science, Ethical relativity.

\section{RESUMEN}

El presente artículo fundamenta la necesidad de utilizar el potencial de la filosofía de la ciencia en el diseño de un proyecto de desarrollo sostenible. Junto con las matemáticas y la informática, la filosofía de la ciencia se considera una ciencia auxiliar diseñada para ayudar a aclarar la naturaleza conceptual y metodológica de las teorías científicas. Se presentan nuevas disposiciones de la filosofía de la ciencia. Se prueba la proposición de que todas las teorías axiológicas culminan en la ética. También se fundamenta que las ciencias naturales demuestran la relatividad ética. El proyecto, es decir, tanto el concepto como la 
concepción (teoría) del desarrollo sostenible, se diseñó sin tener en cuenta los logros de la filosofía de la ciencia, incluida la ética científica. A medida que el proyecto se desarrolló, su contenido no se hizo más claro sino, por el contrario, más oscuro. El proyecto de desarrollo sustentable se reevalúa a la luz de la filosofía de la ciencia. Resulta ser nada más que una paráfrasis de la necesidad del adecuado desarrollo de la relatividad ética de la ecología y su lugar en el sistema de ética científica equilibrada. El proyecto de desarrollo sostenible presenta una paráfrasis de cierto contenido científico que debe ser abordado adecuadamente. Sin esto, no tiene significado científico y debe atribuirse al campo del lenguaje cotidiano. Por tanto, ha llegado el momento de poner el proyecto de desarrollo sostenible en una vía científica.

Palabras clave: Proyecto de desarrollo sostenible, Filosofía de la ciencia, Relatividad ética.

\section{INTRODUCTION}

People are beings who express their preferences in axiological sciences, particularly in economics, technology, medicine, and sociology, through values that function in the form of principles, laws, and variables. In accordance with their nature, people quantitatively multiply and typically maximize their values. In this context, relations of rivalry arise between people, various social groups, and individuals often leading to injustice (Zencey, 2010). Relapses of injustice permeate the entire history of human development. Resisting such relapses is difficult but can be achieved through ethics. The ethical project has been known since time immemorial and there is every reason to believe that it was invented exactly to eradicate injustice. As we can see, the nature of mankind contains the possibility of phenomena that are extremely negative for it. Injustice is not the only danger to human development. Another danger accompanies it due to the indispensable connection of the axiological sciences with their natural neighbors - physics, chemistry, Earth sciences, and biology.

Human values cannot be realized without the use of natural objects. From the point of natural sciences, humanity itself presents a natural formation. In the examined case, this implies that people can harm themselves as natural beings when realizing themselves as axiological beings. As demonstrated in particular by the history of the development of agricultural and industrial production, this harm can and does reach a planetary scale. However, humans are not meek creatures and they mobilize their strengths in the face of danger. To confront the new danger, people are implementing an ecological project according to which nature should be the home of human existence. In this regard, there appears to be an acute need for new conceptual tools. It is in this context that the concept of "sustainable development" becomes the object of our interest.

The start of the popularity of the concept of "sustainable development" is often and not unreasonably associated with the report of the United Nations Commission on Environment and Development headed by Gro Harlem Bruntland (Report of the world commission..., 1987). This report presents the famous definition:

Sustainable development is the development that meets the needs of the present without compromising the ability of future generations to meet their own needs. It contains within it two key concepts:

- the concept of 'needs', in particular the essential needs of the world's poor, to which overriding priority should be given;

- and the idea of limitations imposed by the state of technology and social organization on the environment's ability to meet present and future needs (Report of the world commission..., 1987, p. 43).

Paying tribute to the UN, the basic documents clarifying the content of not only the concept but also the conception of sustainable development were developed under its auspice. Three of these documents 
deserve a mention in this text. The first one is the Rio Declaration on Environment and Development which formulates 27 principles of correct environmental, economic, and social behavior (The Rio Declaration on Environment and Development, 1992). The second one is the UN Millennium Declaration (2000), which defined the development goals of the world community mainly up to 2015 (The Millennium Development Goals, 2015). The third one is Resolution 70/1 adopted by the UN General Assembly on 25 September 2015 which defines 17 Sustainable Development Goals expected to be achieved by 2030 (2015).

In a very detailed review of the history of the development of the sustainable development concept, V. Klarin concluded that it "adapts to the modern requirements of a complex global environment but the basic principles and goals, as well as the problems of their implementation, have practically not changed" (Klarin, 2018, p. 67). He also notes that the goals of sustainable development have mostly not been achieved yet.

Now we have come to the point where it is time to outline the peculiarity of our position. There are countless articles and monographs in which the concept of sustainable development is mainly considered in the light of documents developed and approved by the UN. Scientists of various specializations not only comment on their content but also criticize them. Nevertheless, there is a consensus that the sustainable development project is scientifically sound. Its exact scientific address, i.e. affiliation with a particular branch of science is not defined. It is believed to be interdisciplinary. Meanwhile, the economic, social, and environmental aspects of sustainable development are the ones considered most often. However, these aspects do not exhaust the content of the sustainable development project. It is enough to turn to the above 17 Sustainable Development Goals to be convinced that they include, among other things, the achievement of technological, agricultural, medical, pedagogical, and many other goals. There is no branch of science left out of the sustainable development project. In this regard, we believe that the understanding of the scientific content of the concept of sustainable development leaves much to be desired. It should be not accepted at face value but substantiated in accordance with the most advanced scientific methodology. This means that it is time to give the floor to the philosophy of science.

\section{METHODS}

Attaching paramount importance to methodology, we quite consciously turn to the philosophy of science since it sets the methodological framework for scientific work. There most definitely exist various concepts of the philosophy of science, in particular, the positivist, critical-rationalist, and analytical concepts. In the present study, we focus on the version of the philosophy of science developed by V.A. Kanke (2016; 2020). Kanke summarizes the methodological achievements of all branches of science and modern science is constantly present in the field of his attention as a single whole. In addition, he demonstrates that any axiological theory culminates in ethics. These two features of Kanke's scientific activity are extremely relevant for assessing the status of the sustainable development project as this project is also characterized by an emphasis on the integrity of our worldview and its ethical orientation. Thus, we use the ideas of Kanke to assess the scientific status of the sustainable development project. It is revealed that these ideas allow us to reevaluate the indicated concept and outline the ways of its detailed understanding.

\section{THE MAIN PROVISIONS OF THE PHILOSOPHY OF SCIENCE}

Modern science presents a variety and unity of natural, axiological, and auxiliary theories. Their essences are, respectively, natural objects including systems, social groups, and individuals as uniforms expressing similar features of the existing natural and axiological theories. Axiological theories are represented, for example, by economics, sociology, technology, agricultural theories, and medicine. Natural sciences include physics, chemistry, Earth sciences, and biology. Ancillary theories comprise logic, mathematics, 
computer science, linguistics, and the philosophy of science. Their purpose lies in realizing the potential of natural and axiological theories. Said potential is derived from these theories, generalized into uniforms, developed, and offered to be used by all scientists. Uniforms include, for example, numbers in mathematics, subject and predicate in linguistics, and principles and laws in the philosophy of science.

The range of auxiliary sciences is quite extensive. The wide public is aware of mathematical and computer modeling that uses the potential of mathematics and computer science. It is a less known fact auxiliary sciences include the philosophy of science designed to promote the development of the conceptual and methodological content of scientific theories. In the absence of the implementation of the achievements of the philosophy of science, the nature of a given scientific theory does not receive the due assessment.

Researchers typically use general scientific auxiliary sciences focused on both natural and axiological theories. However, along with the general scientific theories, there also exist axiologically oriented theories including, in particular, ethics and law. Ethics is called upon to comprehensively develop the concept of what is due and law develops the concept of what is permitted.

Principles are the most capacious of all concepts. Usually, principles form some sort of hierarchy. The most relevant are the first principles, for example, the principle of least action in physics and the maximization of the rate of return of advanced capital in economics. The first principle of the philosophy of science is the principle of theoretical representation according to which everything that exists including language, mentality, objects, and subjects are presentations of theories. Willard Quine once put it very well: "even our original objects - bodies - are already theoretical" (Quine, 1981, p. 20). The same thing, namely the initially theoretical nature, can be attributed to mentality, language, and subjects. The very concept of "nature" is also philosophical and in this sense, the idea of "environment" in the way it is put in the concept of sustainable development is a theoretical formation subject to rethinking and axiological reevaluation. At the same time, the understanding of nature and the attitude towards it evolves from era to era. In his work "Philosophy and ecology", V. Hösle examines the evolution of attitudes as the development from inclusive to opposing (Hösle, 1993). We need to understand that various axiological aspects were standing out and dominating at the different stages and forms of the relationship between humanity and nature. Meanwhile, nature (both as a "concept" and as an "environment") has always been valuable for mankind in various forms of interaction with it - from anthropocentric to biocentric, from pragmatic to non-pragmatic, but the value of it differed fundamentally (Korotenko, 2013). The global value of nature for humanity lies in the fact that a human presents a part of it and can exist (and develop) only in the natural environment, but the axiological poles of the discourse of sustainability are presented by the issues of the balance of the transformation of the natural "body of nature" in practical activity.

\section{ERADICATING INJUSTICE IN THE LIGHT OF THE PHILOSOPHY OF SCIENCE}

As was previously noted, we are especially interested in the issue of confronting injustice. We intend to illuminate it from the standpoint of the philosophy of science. In this regard, the following two circumstances are of particular importance. The first one is the fact the ethical systems developed within the framework of philosophy, in particular, the aretological ethics of Aristotle, the deontological ethics of Kant, and the utilitarian ethics of Bentham-Mill, are very far from the demands of axiological sciences.

On the other hand, an acute need for ethics is present in all axiological sciences and all kinds of negative phenomena inevitably manifest themselves in its absence. There is an explicit problematic situation at hand. Kanke proposes the following conceptual steps to resolve it (Kanke, 2020, pp. 27-28). First, it is necessary to re-evaluate the status of ethics. Contrary to popular belief, it is not an independent but an auxiliary science. It initially draws its potential from independent axiological theories. Said potential consists in the fact that the principle of maximizing the well-being of all participants of a given action, i.e. stakeholders, has to appear in these sciences themselves. Second, well-being has to be interpreted in 
accordance with the content of axiological theories. To put it more simply, for example, using the example of economics, prosperity is understood as maximizing the profits of entrepreneurs and the wages of workers and employees (Zencey, 2010). Third, the ethical principle has to be at the head of the hierarchy of the principles of any axiological theory. If it is not put in the first place, relapses of injustice will inevitably arise.

Thus, the main way of confronting injustice is identified. However, it is only defined regarding axiological theories. Meanwhile, axiological sciences make up unity with natural sciences. Fundamentally, none of these sciences can contain ethical principles. Natural objects and biological organisms are alien to ethics. On this basis, it would be inaccurate to separate natural sciences from ethics. The seeming inconsistency of the situation under discussion comes to an end if we assume that natural theories and all of their components possess ethical relativity.

However, it should be understood that actual environmental limits exist regardless of the axiology of our attitude, and these limits - existentials - are what is limiting our existence as biological systems. Natural ecosystems are the "factories of life" for everyone, i.e. life in general. An environment suitable for human life is created and sustainably maintained in a state optimal for the existence of life by natural ecological communities of living organisms undisturbed by mankind - ecosystems that compensate for the environmental disturbances that do not exceed the threshold of the destruction of said system (Korotenko et al., 2015, p. 17).

Mutual dependence, mutual necessity, mutual irreplaceability, and universal cooperation are the great principles of life. These principles are realized in the functioning of natural ecosystems, in the life of wild nature and are still poorly represented in the system of an axiologically grounded foundation of social sciences in general and political and economic doctrines in particular.

The content of natural sciences is interpreted from the point of axiological theories. The natural theories that violate the principle of maximizing human welfare are rejected. Value orientations towards transformation, the reorganization of the "body of nature" within the framework of the scientific paradigm presents a direction of development that is dangerous for universal survival as demonstrated by modern discourses of climate change (IPCC Special Report..., 2019) and the boundaries of planetary safety (Rockström et al., 2009).

The ethical context can most definitely be extrapolated to auxiliary theories, particularly to mathematics, computer science, economics, and management. All auxiliary theories are ethically oriented in the same direction as the independent theories they draw their potential from.

Finally, it should be borne in mind that all sciences form a single whole. The ethical content of all theories has to be kept in balance. The absolutization of the content of one or several particular sciences destroys the unity of the human world.

\section{THE CONCEPT AND CONCEPTION OF SUSTAINABLE DEVELOPMENT IN THE LIGHT OF SCIENTIFIC ETHICS}

The previous sections of the article presented the ways of countering injustice from the standpoint of the philosophy of science and scientific ethics viewed as a set of auxiliary theories which corresponds to its provisions. From these positions, we shall assess the status of the concept and the conception of sustainable development. The concept of sustainable development is a principle of theory. For instance, it can be included in the principles of economics or agrological theories. The concept of sustainable development is more than a principle, namely, it is a theory. For example, UN resolutions and declarations 
on sustainable development containing extensive lists of both principles and goals present the outlines of theories.

The conception of sustainable development unites three areas: economy, society, and natural capital. The model of sustainable development can be structurally presented in the form of a truncated pyramid the foundation of which represents natural ecosystems since it is the entire complex of species of the Earth that makes its surface capable of supporting life. Natural ecosystems form a favorable habitat for living organisms and provide conditions for sustainable development (Korotenko et al., 2015, p. 23). The authors of the sustainable development project were initially concerned about the blunt exploitation of environmental resources by people accompanied by its partial destruction. The environment was seen as a complex of natural systems exposed to the influence of the human community. These kinds of systems present the object of ecology. Thus, the unfavorable state of affairs in the field of ecology was discovered. It was to be considered a violation of the acceptable parameters of the ethical relativity of ecological systems. However, researchers did not have mastery over the concept of ethical relativity and no one was able to find an analog for it in everyday language. The scientific approach to problem-solving involves finding a clear theoretical affiliation for a problem at hand. In the examined case, it should have been about ethics and scientific rather than metaphysical ethics but this need was hardly recognized.

The sustainability of development was understood as ensuring continuous long-term progress. Only under this condition, the present generation of people can provide the space necessary for the development of future generations. This implied that ethical obligations exist not only between contemporaries but also between the previous and subsequent generations. Scientists had to make predictions for different time frames which presented a daunting task.

When it comes to the principle of sustainable development, it is mainly viewed as steady and long-term progress. The need for this form of progress rather than, for example, a constantly accelerating process has never been substantiated. Over the years, the authority of the sustainable development project has become increasingly associated not so much with the principle as with the interdisciplinary theory of such development. A holistic worldview started to be developed on behalf of the sustainable development project.

The proposed theories began to link together extremely diverse ideas, particularly of economic, political, technological, medical, and pedagogical nature. Eric Zencey described this development as follows: the term "sustainability" has started to be used widely to the point of almost losing meaning. It was applied to all types of activity to give these actions the gloss of a moral imperative, the stamp of environmental education. "Sustainable" has been used in various senses to signify "politically feasible", "economically feasible", "not being a part of a social pyramid or bubble", "socially enlightened", "consistent with the neo-conservative dogma of small government", "consistent with the liberal principles of justice and impartiality", "morally desirable", and, in the vaguest form, "reasonably far-sighted" (Zencey, 2010, p. 45).

Dennis Meadows, a co-author of the famous report "The Limits to Growth" to the Club of Rome, also treats the sustainable development project critically (Meadows, 2012). It is easy to see that the more attention is paid to the theory of sustainable development the higher is the interest in its ethical status. At the same time, there prevails a tendency of taking the indicated theory as a basis to supplement it with the known versions of ethics (Korotenko et al., 2015; Salamat, 2016; Wesarat et al., 2017). Essentially, it is stated that there is no sustainable development without ethics and there is no ethics without sustainable development. In our opinion, this position does not explain a lot, specifically, it does not explain the reasons for the concerns of Zencey and Meadows regarding the viability of the sustainable development project. These authors rightfully note that after many years of seemingly confident mastery over the 
concept of sustainable development its content has become not so much clearer as more confusing. Our position on this issue is as follows.

The sustainable development project was not considered from the standpoint of the philosophy of science. Its status as an auxiliary science was underestimated. A lot has been said about various sciences, particularly the economic, social, and environmental sciences but the philosophy of these sciences was not considered. Being largely metaphysical, ethics did not fit properly into the context of scientific theories. In a scientific sense, everything falls into place if the analysis is based on the achievements of the philosophy of science. In this case, it turns out that the clarification of the content of any phenomena relevant to the life of people is achieved in the same way.

First, phenomena are interpreted as representations of scientific theories. Second, axiological theories culminate in ethics. Third, ethical relativity is attributed to the natural sciences, particularly ecology. Fourth, inter-theoretical relations are considered. Fifth, a balanced version of the ratio of special ethics of axiological theories and the ethical relativity of natural theories is determined. From these positions, the sustainable development project receives a re-evaluation. It turns out to be nothing more than a paraphrase of the need for the proper development of the ethical relativity of ecology and the correct determination of its place in the system of balanced scientific ethics.

The sustainable development project certainly presents the importance that is far from secondary. Contrary to Meadows' opinion, it does not present an "oxymoron", i.e. a set of contradictory provisions. The sustainable development project is a paraphrase of certain scientific content that has to be addressed. Without this, the project does not have a clear scientific meaning and should be attributed to the field of everyday language. Thus, it is time to put the sustainable development project on a scientific track and the philosophy of science is the only thing that can be the guiding star on this path.

\section{DISCUSSION}

The sustainable development project has numerous supporters who believe without a shadow of a doubt that the entire history of its development and promotion is scientific. The number of definitions of the sustainable development project continues growing like a snowball. However, all of this does not add to its clarity or practical or any other kind of significance. A lot of discussions are devoted to the unity of economic, social, and environmental sciences but the theories that make up their content are only considered briefly. The good intentions of overcoming poverty, illiteracy, and corruption, stopping environmental pollution and the arms race, and improving public health services, etc. fail to shape the science-based development programs (Wesarat et al., 2017).

The sustainable development project also has several opponents who are mostly concerned about the lack of decisive successes in its implementation at the time of the unprecedented increase in the number of risk factors and global threats to the future of humanity. The problem of the opponents of the sustainable development project is that they do not see an alternative to it. Meanwhile, for all his vagueness, the project points to very real problems. Poverty indeed needs to be battled and the threat of a third world war must be eliminated equally rigorously.

The article describes a worthy modernization of the sustainable development project in the form of a synthesis of the achievements of scientific theories culminating in the ethical content of axiological theories and ethical relativity of natural theories including ecological ones. The proposed paradigm perfectly agrees with the main trends of the centuries-old development of various sciences and, ultimately, their understanding in the philosophy of science. The views of both the enthusiasts and opponents of the sustainable development project do not demonstrate this degree of scientific support. 
The question arises: how can the technocratic mistake made in the formation of a political strategy for global sustainable development be corrected? In our opinion, there are two ways to eliminate this error. First, it is necessary to give a civilizational meaning to the concept of sustainable development; second, the concept of sustainable development has to be enriched with new content supplementing it with humanistic versions of the global information society (Wesarat et al., 2017). The transition to sustainable development is possible only on a global planetary scale which presents another argument in favor of the synthesis of the concept of sustainable development and the idea of a global civilization.

\section{CONCLUSION}

In the form of the sustainable development project, researchers have identified the pressing problems that most certainly have to be addressed. Unfortunately, they were overly carried away by the forms of its development that were insufficiently connected to the content of science, the enormous complex of scientific theories. It has long been known that overcoming problems is impossible without a proper understanding of their nature. This understanding implies an indispensable appeal to the philosophy of science and the comprehension of ethics contained in it. This opportunity was not realized by the enthusiasts of the sustainable development project, as well as by many of its critics. There is not a single technology that can make the world more sustainable despite the cultural dimension. New technologies alone can not lead to sustainability. To avoid collapse, it is necessary to change the habits, behavior, and goals that we pursue. It is necessary to account for the sustainability component in making all decisions to form a new conceptual language allowing to discuss the environmental aspects of the programs for the development of social systems. The currently predominant management cultures have formed a "language of consumption" of nature while a "language of conservation" is lacking. This is a language that would make us more eager to talk about the existence of complex, heterogeneous systems including those ethically predetermined and axiologically oriented regarding the concept of preservation, reconstruction, and destruction of the existing natural mechanisms.

The significance of this article is that we have introduced such a possibility, i.e. an alternative to the sustainable development project that does not simply negate it but allows us to take its positive aspects into account. The sustainable development project is capable of retaining its relevance but only if it is transferred into the scientific field.

\section{REFERENCES}

Hösle, V. (1993). Filosofiia i ekologiia [Philosophy and ecology]. Moscow: Science.

IPCC Special Report on Climate Change, Desertification, Land Degradation, Sustainable Land Management, Food Security, and Greenhouse gas fluxes in Terrestrial Ecosystems. (2019). IPCC. Retrieved from: https://www.ipcc.ch/site/assets/uploads/sites/4/2020/06/SRCCL-TS Updated-fromFGD_28-April_Final.pdf

Kanke, V.A. (2016). Filosofskie problemy nauki i tekhniki [Philosophical problems of science and technology]. Moscow: Iurait.

Kanke, V.A. (2020). Etika otvetstvennosti [Ethics of responsibility]. Moscow: Infra-M.

Klarin, T. (2018). The Concept of sustainable development: from its beginning to the contemporary issues. Zagreb International Review of Economics \& Business, 21(1), 67-94.

Korotenko, V. (2013). Phenomenon of ecological consciousness: theory and interpretation. Proceedings of the XXIII World Congress of Philosophy, Athens, 4-10 August 2013. 
Korotenko, V.A., Shukurov, E.Dzh., Kirilenko, A.V., Vashneva, N.S. (2015). Ekologicheskaia bezopasnosti $\mathrm{v}$ kontekste ustoichivogo razvitiia Kyrgyzstana [Ecological safety in the context of sustainable development of Kyrgyzstan]. Bishkek.

Meadows, D. (2012). The Limits to Growth: It is too late for sustainable development. Moscow: Moscow State University.

Quine, W.V.O. (1981). Theories and Things. Cambridge: Harvard University Press.

Report of the world commission on environment and development: our common future. (1987). UNCED. Retrieved from: http://www.un-documents.net/wced-ocf.htm

Resolution 70/1, adopted by the General Assembly on 25 September 2015. (2015). Transforming Our World: The 2030 Agenda for Sustainable Development. UN. Retrieved from: https://www.un.org/ga/search/view_doc.asp?symbol=A/RES/70/1\&Lang=R/

Rockström, J., Steffen, W., Noone, K., Persson, Å., Chapin, F. S. Iii, Lambin, E., Lenton, T. M., Scheffer, M., Folke, C., Schellnhuber, H., Nykvist, B., De Wit, C. A., Hughes, T., Van Der Leeuw, S., Rodhe, H., Sörlin, S., Snyder, P. K., Costanza, R., Svedin, U., Falkenmark, M., Karlberg, L., Corell, R. W., Fabry, V. J., Hansen, J., Walker, B., Liverman, D., Richardson, K., Crutzen, P., Foley, J. (2009). Planetary boundaries: exploring the safe operating space for humanity. Ecology and Society, 14(2), 1-33.

Salamat, M.R. (2016). Ethics of sustainable development: the moral imperative for the effective implementation of the 2030 Agenda for Sustainable Development. Natural Resources Forum, 40, 3-5.

The Millennium Development Goals. (2015). UN. Retrieved from: http://www.un.org/ru/millenniumgoals/mdgreport2015.pdf

The Rio Declaration on Environment and Development. (1992). UN. Retrieved from: https://www.un.org/ru/documents/decl_conv/declarations/riodecl.shtml

Wesarat, P., Sharif, M.Y., Majid, A.H.A. (2017). Role of organizational ethics in sustainable development: a conceptual framework. International Journal Sustainable Future for Human Security. JSustaiN, 5(1), 67-76.

Zencey, E. (2010). Theses on Sustainability: A primer. Orion Magazine, 29(3), 45-48. 